2. Central Drugs Standard Control Organization: Ethics Committee ReRegistration [cited 2019 Nov 1]. Available from: https://cdsco.gov.in/ opencms/opencms/en/Clinical-Trial/Ethics-Committee/EthicsCommittee-Re-Registration/

3. Department of Health Research, Ministry of Health \& Family Welfare, Government of India. National Ethics Committee Registry for Biomedical and Health Research (NECRBHR) . [cited 2019 Nov 1]. Available from: https://naitik.gov.in/DHR/Homepage

4. Indian Council of Medical Research. National Ethical Guidelines for Biomedical and Health Research Involving Human participants. New Delhi: ICMR; 2017. [cited 2018 Apr 20]. Available from: http:// www.icmr.nic.in/guidelines/ICMR_Ethical_Guidelines_2017.pdf

5. Ghosh S, Shetty RS, Pattanshetty SM, Mallya SD, Pandey D, Kabekkodu $\mathrm{SP}$, et al. Human papilloma and other DNA virus infections of the cervix: A population based comparative study among tribal and general population in India. PLoS One. 2019 Jun 27;14(6):e0219173.

6. Kuyare SS, Marathe PA, Shetty YC, Kamat SK, Katkar J V, Thatte UM. Projects not initiated by investigators: a retrospective analysis of the queries raised by the institutional ethics committees of a teaching hospital. J Postgrad Med. 2014; 60(1):46-50.

7. Jalgaonkar S V, Bhide SS, Tripathi RK, Shetty YC, Marathe PA, Katkar J, et al. An audit of protocol deviations submitted to an institutional ethics committee of a tertiary care hospital. PLoS One. 2016 Jan 6;11(1):e0146334.Doi: https://doi.org/10.1371/journal.pone.0146334

8. Tripathi RK, Marathe PA, Kapse S V, Shetty YC, Kamat SK, Thatte UM. Serious adverse events reports: Analysis and outcome of review by an institutional ethics committee of a tertiary care hospital in Mumbai, India. J Empir Res Hum Res Ethics. 2016;11(3):267-73.

\title{
Opposition to Haryana government's medical education directive: not just about the fee hike
}

MOHIT P GANDHI

\begin{abstract}
A recent directive of the Haryana government has linked the MBBS course offered by the state government medical colleges to an annual bond of $R s$ 10 lakh. This move has been opposed by medical aspirants, medical students, as well as the medical association as it will further reduce avenues for affordable medical education. While this is indeed a grave concern, there is more that needs to be considered.
\end{abstract}

Keywords: Doctor shortage, service bond, social orientation, medical pedagogy, primary healthcare

The state government of Haryana has recently revised the fee structure for the MBBS course in its government medical colleges (1). A student will now have to execute a bond of Rs 10 lakh every year for the four-and-a-half-year course, which adds up to a minimum of Rs. 45 lakhs. This includes the annual tuition fee of Rs. 80,000 . The students may decide to pay the amount out-of-pocket each year and be free to do whatever they want after finishing the course ("Option B"). Or, they may commit to joining state government service after graduation. In this case, the State will help them get a loan

Author: Mohit P Gandhi (mohit.p.gandhi@gmail.com), Public Health Professional, 25, Mahesh Nagar Extension B, Jaipur, Rajasthan, 302015 INDIA.

To cite: Gandhi MP. Opposition to Haryana government's medical education directive: not just about the fee hike. Indian J Med Ethics. 2021 Oct-Dec; 6(4) NS: 326-28. DOI: 10.20529/IJME.2021.037.

Published online first on May 14, 2021

(c) Indian Journal of Medical Ethics 2021 while they are studying; and will start repaying it on their behalf once they join the service ("Option A"). It will take seven years for the loan amount to be fully repaid. In case the candidate wishes to leave the service at any time within the seven-year period, s/he may settle the balance amount out-of pocket and leave. The directive also allows students to switch from Option B to Option A at the beginning of any of the academic years of the course.

Before this directive, the fee was around Rs. 50,000/year, and there was no bond. By this directive, the government claims to incentivise doctors to opt for government service and to strengthen medical facilities in the State. However, "This policy does not make it mandatory/obligatory for the State Government to provide employment to the MBBS graduate" (1).

\section{Why does this need to be opposed?}

Almost half of the 542 medical colleges (MCs) in India are under non-government ownership (2). The fees in most of these colleges, even if the initial capitation is ignored, are beyond the reach of even the middle class. If the government MCs also hike their fees on such an astronomical scale, access to medical education (ME) will get limited only to the rich elite.

"Option A" appears to be a way out for those who cannot afford to pay this amount. Under this option, the State government will repay the loans of those students who join the government service after graduation. But, strangely enough, the State government has absolved itself outright of the responsibility to provide jobs to these graduates. Thus, one wonders if this is just a ploy to promote private MCs. If those colleges bring down their fees to below Rs 10 lakhs per year, a 
section of students, who would otherwise have preferred government MCs, may now shift to private ones.

Yes, as a society, we should have resisted the commercialisation of ME a long time ago, when the politician-businessmanbureaucrat nexus had started wreaking havoc in this sector. But then, keeping education affordable in public institutions is still worth fighting for. So, all power to those who are opposing this move!

\section{The larger concerns}

As per Rural Health Statistics (2018-19), 7,715 out of 32,824 (24\%) positions of allopathic doctors at primary health centres in India, and 3,747 out of 16,448 (23\%) at community health centres, are lying vacant (3). This is the situation when there are 80,205 MBBS seats in the country (2).

One of the many reasons for this sorry state of affairs is the aversion of medical graduates to joining the public health sector. This aversion is, in itself, part of a bigger and more complex problem, which is that medical students do not wish to halt, or even pause after graduation. Instead, they crave immediate entry into post-graduation (PG). The students, however, are only responding to what "their" society expects of them. Which middle/upper-class family wants its son/daughter to be just a general physician? And which middle/upper-class patient wants to consult a doctor who is "just an MBBS", even for primary complaints? When there is no demand, there is no supply. Even those few students who come from a relatively modest background get tempted to follow their peers.

More importantly, the undergraduate ME, which is aimed at producing "basic" doctors, takes place almost entirely in a tertiary-level set-up. Most of the time, students see complicated cases requiring sophisticated diagnostics and procedures. The surgeons and physicians, who "heroically" try to save lives, become their role models. Exposure to primarylevel medical care, and those who provide it, is minimal. At the same time, the private coaching industry starts offering pre-PG preparatory courses as early as the second-year MBBS. Consequently, learning and skill-development during the undergraduate course get compromised. Thus, the graduates are neither keen to, nor capable of, starting an independent practice.

Further downstream, joining the public services (hereinafter "services") at primary-level comes with its own challenges. After spending so many years in an MC, most of which are in big cities, the option of working in a small town/village with much fewer facilities, is not very appealing to graduates. The issues related to human resources, logistics and infrastructure, which are emblematic of public set-ups, further reduce the interest. The bureaucracy, local politics, and the non-medical components of work at this level these are not challenges the medical graduate is prepared to handle. And then, the way the public system treats its doctors is no secret. To expect fresh graduates to "willingly" join the services in these prevailing circumstances is, thus, wishful thinking.

\section{Existing remedies}

The medical needs of communities that entirely depend on the public system cannot and should not be ignored. And so, several ideas have been and are being tried out in parallel (4). AYUSH graduates, as if they are lesser humans, are being lured into places where allopathic graduates do not want to work. Talk of cadres like Rural Medical Assistants and Nurse Practitioners also keeps popping up. The allopathic fraternity invariably opposes all these options, albeit without suggesting any alternative solution (4).

Several states have, for long, tried to "push" medical graduates into the services by making them sign a one-time bond at the beginning of the MBBS course. This approach has had only limited success because of lack of monitoring of compliance. Another approach has been to entice graduates by offering them preference in the selection for post graduate courses, which has worked relatively better (5). But in either case, those who are rich enough to pay the penalty in lieu of the bond, or are "intelligent" enough to clear the pre-PG entrance without any preferential treatment, are able to escape obligatory government service. Meanwhile, those who do join it, just wait for the mandatory period to get over. They would otherwise not want to do that work. What quality of medical care can such "bonded" graduates be expected to provide?

\section{Dialogue, not diktat}

The directive issued by the Haryana government suffers from the same malaise. It aims to selectively push those medical graduates who can't afford the hiked fee into the services. The State's Department of ME gives no direction so as to prepare medical students, technically and emotionally, for the services. And the government makes no commitment to making the services socially respectable, economically viable and professionally satisfying.

Public healthcare services, besides several other interventions, desperately need doctors. But this issue has to be settled through a much more inclusive process and not by issuing bureaucratic diktats. Institutions like Christian Medical College, Vellore, St. John's Medical College, Bengaluru, and Mahatma Gandhi Institute of Medical Sciences, Sevagram, have experience in motivating and enabling their graduates to join the rural service $(6,7)$. The success has been limited, but even so, that experience is worth looking into so as to make the students "want" to join the services. And then, such a directive has to be universal. If there is no escape from joining government service, students will accept it more readily. With time, this will become the natural course of the stream.

This directive of the Haryana government needs to be vehemently opposed. But the opposition should not be restricted only to the increase in fees. 


\section{Conflict of interest and funding: None declared.}

\section{References}

1. Department of Medical Education and Research, Government of Haryana. Notification (No. 16/17/2019-6HBIV dated 6th November 2020 [cited 2020 Nov 12]. Available from: http://dmerharyana.org/ wp-content/uploads/2020/11/Policy.pdf

2. National Medical Commission. List of Colleges teaching MBBS in India. Date unknown [cited 2020 Nov 12]. Available from: https:// www.nmc.org.in/information-desk/for-students-to-study-in-india/ list-of-college-teaching-mbbs

3. Ministry of Health and Family Welfare, Govt of India. Rural Health Statistics 2018-19[cited 2020 Nov 12]. pp 158 and 168. Available from:https://main.mohfw.gov.in/sites/default/files/ Final\%20RHS\%202018-19_0.pdf
4. Sharma DC. India still struggles with rural doctor shortages. Lancet 2015 Dec 12; 386 (10011): 2381-2. Doi: 10.1016/S0140 6736(15)01231-3.

5. Shroff ZC, Murthy S, Rao KD. Attracting doctors to rural areas: A case study of the post-graduate seat reservation scheme in Andhra Pradesh. Indian J Community Med. 2013 Jan; 38(1):27-32. Doi: 10.4103/0970-0218.106624

6. Deshpande SR. Rural and urban health training centres of medical colleges in India: A prescription for their revamp. Natl Med J India. 2015 May-Jun; 28(3):141-3.

7. Observations and Interviews conducted by the author during 2018 19 for his doctoral thesis titled 'Understanding of Primary Health Care among Faculty of Community Medicine in India: A Study of Knowledge, Perceptions and Pedagogy, under the supervision of Prof. Ritu Priya (Jawaharlal Nehru University, New Delhi).

\section{The Spiral}

\section{RAKHI GHOSHAL}

Episodes of domestic violence are incredibly more common than what is documented. While we have had a law against it in India since 2005, the prevalence of domestic violence is high in India at close to 30 percent (as per National Family Health Survey, 2015-16). Yet, with interventions such as Dilaasa in Maharashtra, Bhoomika in Kerala, and Sukoon in Haryana - among others visibility has increased; and so has support seeking behaviour. The narrative here is based on my personal observation - with some extensions from my imagination built in to give a structure to the narrative - which jarred as I saw how the consequences of violence can be so debilitating, how violence begets more violence ${ }^{*}$, becomes a question of contingent power; how it flows on through the survivor, creating more survivors.

She walked out the day he hit her with a hot ladle. Dragging her wailing four-year-old along and holding an oil stained cloth duster to a bleeding forehead, she left the one-room tenement that had been her address these past six years, as soon as her husband went up to the terrace for his evening smoke; a neighbour called out after her, surprised, but she rushed past him. Time is surely short when one is running away.

\section{$* * * * *$}

Author: Rakhi Ghoshal (rakhi.ghoshal@gmail.com), Project Manager, 'Health Systems Response to Gender Based Violence' CARE India, Patna, Bihar, INDIA.

To cite: Ghoshal R. The Spiral. Indian J Med Ethics. 2021 Oct-Dec; 6(4) NS: 328 30. DOI: 10.20529/IJME.2021.032.

Published online on May 1, 2021.

Manuscript Editor: Olinda Timms

(c) Indian Journal of Medical Ethics 2021
I met Shabnam, a 25-year-old driven-up-the-wall woman at a crisis counselling centre at a public hospital in Mumbai. She had come with her aunt, who waited outside, barely managing to keep up with the skinny, hyperactive four-year-old boy she was baby-sitting ever since Shabnam had taken shelter at her house. Shabnam was dry eyed, tears had fossilised long since and now her eyes burnt like embers. The scar left behind by the gash was just over a month old. Shabnam shared with the counsellor how the beatings had increased over the past six months; she said she did not want to go back to that house, and at the same time she knew she could not stay with her aunt for long; her uncle was ill and there were serious space issues in the house. Shabnam did not know where to go.

Shabnam had had a job till she moved to her aunt's house, and it was the job that had been the root of the everescalating arguments; her husband suspected her of infidelity at the workplace and insisted that she give up the job. She used to work as a saleswoman at a big departmental store, on a 10-hour shift, six days a week, earning 12 thousand a month. Once she moved to her aunt's house, she was too far away from her workplace to make it on time every day. Also, she could not leave her son to be taken care of by the elderly lady alone. The boy had not been going to school ever since she had moved out. Shabnam was angry that her husband had finally succeeded in making her give up her job. The fossilised anger glowed in the tips of her fingernails, the edges of which she bit off from time to time. I watched her in silence, I was observing the counselling session - a social science fly on the wall.

Shabnam started off easily, very unlike the other survivors who took a lot of prodding to open up; she told us of the slaps 